\section{JURNAL EKONOMI}

EFEKTIF
ISSN : $2622-8882$, E-ISSN : 2622-9935

Jurnal Ekonomi Efektif, Vol. 2, No. 1, Oktober 2019

@.Prodi Manajemen Fakultas Ekonomi Universitas

Pamulang

\title{
PENGARUH PERPUTARAN KAS DAN PERPUTARAN PIUTANG TERHADAP RETURN ON INVESTMENT (ROI) PADA PT. SEMEN INDONESIA (PERSERO) TBK PERIODE TAHUN 2008 - 2017
}

\author{
${ }^{1}$ Bulan Oktrima, Novratilova Riani \\ 1dosen00790@unpam.ac.id
}

\begin{abstract}
ABSTRAK
Tujuan penelitian ini dapat mengetahui pengaruh perputaran kas dan perputaran piutang terhadap return on investment pada PT Semen Indonesia (Persero) Tbk. Baik secara parsial maupun simultan periode tahun 2008 - 2017. Data yang digunakan dalam penelitian ini adalah data sekunder yang bersumber dari data keuangan di IDNFinancials yang terdapat dalam laporan keuangan perusahaan periode tahun 2008-2017. Variabel independen yang di uji dalam penelitian ini yaitu perputaran kas dan perputaran piutang. Sedangkan variabel depeden yang digunakan adalah return on investment (ROI). Metode penelitian ini menggunakan analisis statistik yaitu uji asumsi klasik, regresi linier, koefisien korelasi, pengujian hipotesis dengan menggunakan uji $\mathrm{t}$ dan uji $\mathrm{f}$ dan koefisiensi determinasi. Secara parsial (uji-t) diperoleh perputaran kas $\left(\mathrm{X}_{1}\right)$ berpengaruh negatif signifikan terhadap ROI, sedangkan perputaran piutang berpengaruh positif signifikan $\left(\mathrm{X}_{2}\right)$. Secara Simultan (uji f) diperoleh perputaran kas $\left(\mathrm{X}_{1}\right)$ dan perputaran piutang $\left(\mathrm{X}_{2}\right)$ berpengaruh signifikan terhadap return on investment. Berdasarkan R Square variabel independen perputaran kas dan perputaran piutang mempunyai konstribusi sebesar 97,3\% terhadap variabel dependen yaitu ROI.
\end{abstract}

\section{Kata Kunci : Perputaran Kas, Perputaran Piutang, dan Return On Investment (ROI)}

\section{ABSTRACT}

The purpose of this research can determine the effect of cash turnover and accounts receivable turnover on return on investment at PT Semen Indonesia (Persero) Tbk. Both partially and simultaneously the period 2008-2017. The data used in this study are secondary data sourced from financial data at IDNFinancials contained in the company's financial statements for the period 2008-2017. The independent variables tested in this study are cash turnover and accounts receivable turnover. While the dependent variable used is return on investment (ROI). This research method uses statistical analysis that is the classic assumption test, linear regression, correlation coefficient, hypothesis testing using $t$ test and $f$ test and coefficient of determination. Partially (t-test) obtained cash turnover (X1) has a significant negative effect on ROI, while accounts receivable turnover has a significant positive effect (X2). Simultaneously ( $f$ test) obtained cash turnover (X1) and accounts receivable turnover (X2) have a significant effect on return on investment. Based on $R$ Square the independent variables are cash turnover and accounts receivable turnover which has a contribution of 97.3\% to the dependent variable, namely ROI.

Keywords: Cash Turnover, Receivable Turnover, and Return On Investment (ROI) 


\section{PENDAHULUAN}

\section{A. Latar Belakang}

Aktivitas yang dilakukan oleh perusahaan selalu memerlukan dana, baik untuk membiayai kegiatan operasional sehari-hari maupun untuk membiayai investasi jangka panjangnya. Dana yang digunakan untuk melangsungkan kegiatan operasional sehari-hari disebut modal kerja. Modal kerja ini akan terus berputar di dalam perusahaan.

Perusahaan yang menjadi subjek dalam penelitian ini adalah PT. Semen Indonesia (Persero) Tbk merupakan perusahaan yang bergerak dibidang industri semen, perusahaan terkemuka dalam bidang ritel matrial, dan produsen semen terbesar di Indonesia. Pada tanggal 20 Desember 2012, resmi berganti nama dari sebelumnya bernama PT Semen Gresik (Persero) Tbk. Diresmikan di Gresik pada tanggal 7 Agustus 1957 oleh presiden RI pertama. Pada tanggal $\underline{8 \text { Juli }} 1991$ Semen Gresik tercatat di Bursa Efek Jakarta dan Bursa Efek Surabaya sehingga menjadikannya BUMN pertama yang go public. Semen Indonesia (Persero) Tbk memiliki anak perusahaan PT Semen Gresik, PT Semen Padang, PT Semen Tonasa dan Thang Long Cement.

Kaitannya dengan pembahasan diatas dalam rangka meningkatkan keuntungan perusahaan, peneliti menggunakan perputaran kas dan perputaran piutang sebagai alat untuk mengukur kemampuan perusahaan dalam memperoleh keuntungan.

Tabel 1.1

Data Perputaran Kas, Perputaran Piutang, dan Return On Investment PT. Semen Indonesia (Persero) Tbk Periode 2008 - 2017

\begin{tabular}{|c|c|c|c|}
\hline Tahun & Perputaran Kas & $\begin{array}{l}\text { Perputaran } \\
\text { Piutang }\end{array}$ & $\begin{array}{c}\text { Return On } \\
\text { Investment }\end{array}$ \\
\hline 2008 & 3.72 & 9.07 & $23.80 \%$ \\
\hline 2009 & 3.61 & 9.73 & $25.68 \%$ \\
\hline 2010 & 3.58 & 8.97 & $23.35 \%$ \\
\hline 2011 & 4.54 & 9.04 & $20.12 \%$ \\
\hline 2012 & 6.02 & 8.94 & $18.54 \%$ \\
\hline 2013 & 7.92 & 9.04 & $17.39 \%$ \\
\hline 2014 & 5.97 & 7.86 & $16.24 \%$ \\
\hline 2015 & 6.04 & 7.63 & $11.86 \%$ \\
\hline 2016 & 7.64 & 6.84 & $10.25 \%$ \\
\hline 2017 & 8.54 & 6.17 & $4.17 \%$ \\
\hline
\end{tabular}

Sumber: Data Diolah (2018)

Berdasarkan data pada tabel 1.1, data laporan keuangan tersebut diperoleh melalui www.IDNFinancial.com, dimana merupakan perusahaanyang terdaftar di BEI, maka dapat digambarkan menjadi grafik seperti dibawah ini 


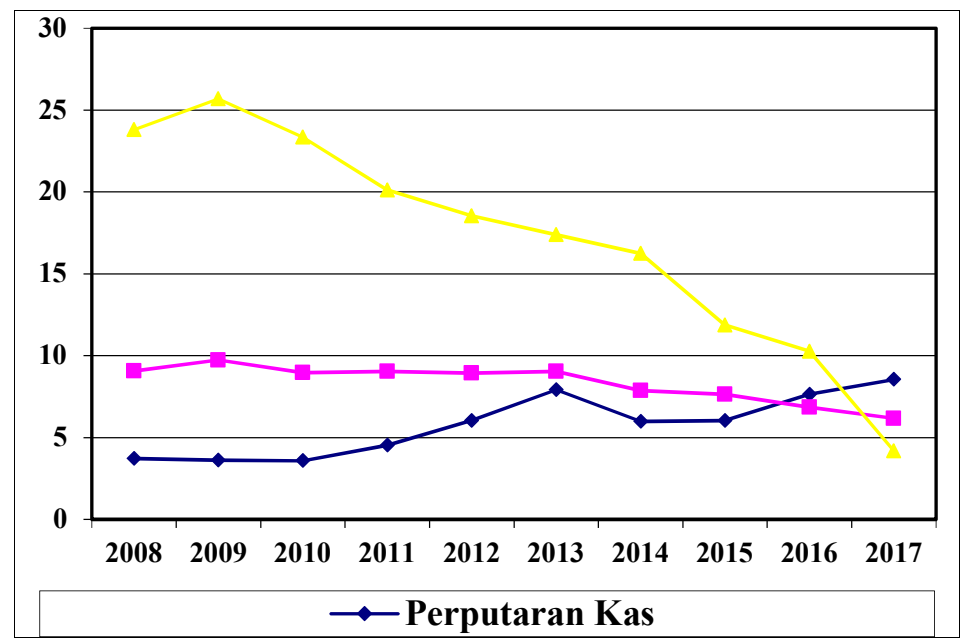

Sumber: Data Diolah (2018)

Grafik 1.1

Data Perputaran Kas, Perputaran Piutang, dan Return On Investment PT. Semen Indonesia (Persero) Tbk Periode 2008 - 2017

Dari Tabel 1.1, perputaran kas dan perputaran piutang, dan ROI selama sepuluh tahun mengalami fluktuasi. Secara keseluruhan keadaan perputaran piutang perusahaan tertinggi pada tahun 2009 sebanyak 9,73 kali mengakibatkan perputaran kas mengalami penurunan sebesar 3,61 kali dan return on investment mengalami kenaikan sebesar 25,68\%. Sedangkan pada tahun 2017 perputaran piutang mengalami penurunan sebesar 6.17 kali mengakibatkan perputaran kas mengalami kenaikan sebesar 8.54 kali dan return oninvestment mengalami penurunan sebesar $4.17 \%$.

Berdasarkan uraian tersebut di atas, maka peneliti tertarik untuk melakukan penelitian lebih lanjut dengan judul "Pengaruh Perputaran Kas dan Perputaran Piutang Terhadap Return On Investment (ROI) pada PT. Semen Indonesia (Persero) Tbk. Periode Tahun 2008 - 2017."

\section{B. Identifikasi Masalah}

Berdasarkan latar belakang, dapat diidentifikasi masalah-masalah sebagai berikut:

1. Peputaran kas mengalami penurunan pada tahun 2014 sebesar 5,97 kali. Kas yang terlalu besar berakibat pemanfaatan kas tersebut kurang efisien karena kas tersebut menganggur dan tidak menghasilkan keuntungan.

2. Perputaran piutang mengalami penurunan pada tahun 2017 sebesar $6.17 \mathrm{kali}$, hal ini menandakan bahwa pengembalian dana pada perusahaan berlangsung lambat.

3. Return on investment (ROI) mengalami penurunan pada tahun 2017 sebesar $4,17 \mathrm{kali}$, hal tersebut dapat terjadi karena pada tahun 2017 perputaran piutang mengalami penurunan, sehingga mengakibatkan tingkat pengembalian kas menjadi menurun.

\section{Rumusan Masalah}

Pembahasan masalah seperti yang dikemukakan di atas, maka rumusan masalah dalam penelitian ini adalah sebagai berikut :

1. Apakah terdapat pengaruh perputaran kas terhadap return on investment pada PT Semen Indonesia (Persero) Tbk., Periode Tahun 2008 - 2017 ? 
2. Apakah terdapat pengaruh perputaran piutang terhadap return on investment pada PT Semen Indonesia (Persero) Tbk., Periode Tahun 2008 - 2017 ?

3. Apakah terdapat pengaruh perputaran kas dan perputaran piutang secara bersama-sama terhadap return on investment pada PT Semen Indonesia (Persero) Tbk., Periode Tahun 2008 - 2017?

\section{TINJAUAN PUSTAKA}

\section{A. Perputaran Kas}

Merupakan frekuensi berputarnya kas yang digunakan untuk proses produksi dan kembali menjadi kas. Perbandingan antara penjualan bersih dengan rata-rata kas mencerminkan tingkat perputaran kas. Tingkat perputaran kas akan dapat mengetahui tingkat efisiensi yang dapat dicapai perusahaan dalam mengelola kas untuk mencapai tujuan dari perusahaan itu sendiri. Yang dimaksud dengan perputaran kas adalah berapa kali kas berputar dalam suatu periode tertentu melalui penjualan barang atau jasa.

Menurut James O. Gill (dalam buku Kasmir, 2010:140), digunakan untuk mengukur tingkat kecukupan modal kerja perusahaan yang dibutuhkan untuk membayar tagihan dan membiayai penjualan. Menurut Bambang Riyanto (2011:95), Perputaran kas adalah perbandingan antara penjualan dengan kas rata-rata. Jumlah kas dapat pula dihubungkan dengan jumlah penjualan atau salesnya. Perbandingan antara sale dengan jumlah kas rata-rata menggambarkan tingkat perputaran kas (cash turnover).

Likuiditas perusahaanm dapat terjaga dengan membuat perkiraan mengenai perputaran kasnya. Semakin tinggi perputaran kasnya akan semakin baik kondisi perusahaan. Sebaliknya jika perputaran kas perusahaan sering mengalami penyimpangan maka perusahaan harus berusaha untuk selalu menjaga persediaan kas minimal. Perputaran kas, Menurut Bambang Riyanto (2011:95), rata-rata kas dalam perhitungan ini adalah kas akhir yang diperoleh ditambah dengan kas awal dibagi dua.

$$
\begin{gathered}
\text { Peputaran Kas }=\frac{\text { Penjuan }}{\text { Rata }- \text { rata Kas }} \\
\text { Rata }- \text { rata Kas }=\frac{\text { Kas Awal }+ \text { Kas Akhir }}{2}
\end{gathered}
$$

\section{B. Perputaran Piutang}

Menurut (Wild, Subramayam, dan Halsey, 2005) Perputaran Piutang adalah menunjukkan rata-rata seberapa sering piutang berubah, yaitu berubah saat diterima dan ditagih dalam satu periode. Rumus perputaran piutang yaitu :

$$
\begin{aligned}
\text { Perputaran Piutang } & =\frac{\text { Penjualan Kredit Bersih }}{\text { Rata }- \text { rata Piutang }} \\
\text { Rata }- \text { rata Piutang } & =\frac{\text { Piutang Awal Tahun }+ \text { Piutang Akhir Tahun }}{2}
\end{aligned}
$$

\section{Return On Investment (ROI)}

Semakin tinggi rasio ini maka semakin baik keadaan suatu perusahaan. ROI merupaka rasio yang menunjukkan berapa besar laba bersih diperoleh perusahaan bila diukur dari nilai aktiva (Syafri, 2008:63).

$$
\text { Return On Investment }=\frac{\text { Laba Bersih Setelah Pajak }}{\text { Total Aktiva }} \times 100 \%
$$




\section{METODOLOGI PENELITIAN}

Objek penelitian iniberalamat di Jalan Veteran, Gresik 61122, Jawa Timur.Proses ini dimulai dari identifikasi masalah, pengumpulan data, penetapan judul, studi literature sampai penyusunan penelitian.

Metode dan Analisis Data yang dianalisis dalam penelitian ini berkaitan dengan hubungan antara variabel-veriabel. Wiratna Sujarweni (2015:121) mengemukakan analisis data diartikan sebagai upaya data yang sudah tersedia kemudian diolah dengan statistik dan dapat digunakan untuk menjawab rumusan dalam penelitian. Dengan demikian analisis data dapat diartikan sebagai cara melaksanakan analisis terhadap data.

Pengujian Asumsi Klasik, Menurut Priyatno (2012:143), model regresi dapat disebut sebagai model yang baik jika model tersebut memenuhi beberapa asumsi yang kemudian disebut dengan asumsi klasik. Asumsi klasik yang harus terpenuhi dalam model regresi linier yang residual terdistribusi normal, tidak adanya multikolonieritas, tidak adanya heroskedasitas, dan tidak adanya autokorelasi pada model regresi. Ada empat uji asumsi yang harus dilakukan terhadap suatu model regresi tersebut, yaitu: Uji Normalitas, uji multikolinieritas, uji Heteroskedastisitas, dan uji autokorelasi.

Analisis Regresi Berganda digunakan untuk mengkaji pengaruh beberapa variabel independen terhadap satu variabel dependen. Dalam regresi linier berganda ditetapkan bila terdapat variabel independen minimal dua atau lebih dari dua. Persamaan linier berganda untuk ketiga variabel ini adalah: $Y=a+b_{1} X_{1}+b_{2} X_{2}+\ldots .+b_{n} X_{n}+e$.

Koefisien Korelasi Menurut Ghozali (2010: 9), analisis korelasi bertujuan untuk mengukur kekuatan asosiasi (hubungan) linier antara dua variabel. Besarnya koefisiensi mengukur kuatnya asosiasi linier. Besarnya koefisiensi korelasi (r) antara dua variabel adalah untuk memberikan interprestasi terhadap kuat atau lemahnya hubungan kedua variabel.

Koefisien Determinasi dengan menghitung koefisiensi penentu, yaitu untuk mengetahui seberapa besar presentase kontribusi atau sumbangan perputaran kas dan perputaran piutang terhadap tingkat return on investment.

Uji Hipotesis, terdapat Uji t Parsial. Menurut Priyatno (2012:139), uji t atau uji koefisien regresi secara parsial digunakan untuk mengetahui apakah secara parsial variabel independen berpengaruh secara signifikan atau tidak terhadap variabel dependen. Nilai dari uji $\mathrm{t}$ dapat dilihat dengan menggunakan tingkat signifikan 0,05 $(\alpha=5 \%)$. Dan terdapat uji F (simultan) Menurut Priyatno (2012:137), uji F atau uji koefisien regresi secara bersama-sama digunakan untuk mengetahui apakah secara bersama-sama variabel independen berpengaruh signifikan terhadap variabel dependen. Nilai dari uji $\mathrm{F}$ dapat dilihat dengan menggunakan tingkat signifikan $0,05(\alpha=5 \%)$.

Menurut Sugiyono (2012:28), Hipotesis merupakan jawaban yang sifatnya sementara terhadap masalah. Berdasarkan uraian di atas peneliti mengambil kesimpulan sementara untuk memecahkan masalah tersebut. Maka peneliti membuat hipotesis sebagai berikut :

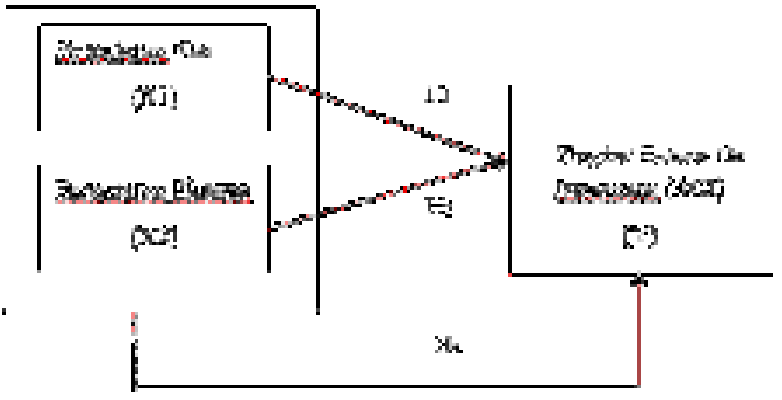

Gambar 3.1

Kerangka Berfikir 
$\mathrm{H}_{\mathrm{a} 1}$ : Terdapat pengaruh antara Perputaran Kas terhadap Return On Investment (ROI) pada PT. Semen Indonesia (Persero) Tbk., Periode Tahun 2008 - 2017.

$\mathrm{H}_{\mathrm{a} 2}$ : Terdapat pengaruh antara Perputaran Piutang terhadap Return On Investment (ROI) pada PT. Semen Indonesia (Persero) Tbk., Periode Tahun 2008 - 2017.

$\mathrm{H}_{\mathrm{a} 3}$ : Terdapat pengaruh antara Perputaran Kas dan Perputaran Piutang secara Bersamasama terhadap Return On Investment (ROI) pada PT. Semen Indonesia (Persero) Tbk., Periode Tahun 2008 - 2017.

\section{PEMBAHASAN}

Pengujian asumsi klasik dilakukan untuk melihat model yang diteliti mengalami klasik atau tidak. Sehingga pemeriksaan penyimpangan terhadap asumsi klasik ini perlu dilakukan.

Tabel 4.1

Hasil Uji Normalitas

One-Sample Kolmogorov-Smirnov Test

\begin{tabular}{|ll|r|}
\hline & & \multicolumn{1}{|c|}{$\begin{array}{c}\text { Return On } \\
\text { Investment }\end{array}$} \\
\hline $\mathrm{N}$ & Mean & 10 \\
Normal Parameters & Std. & .1714 \\
& Deviation & .06759 \\
Most Extreme & Absolute & .147 \\
Differences & Positive & .103 \\
Kolmogorov-Smirnov Z & -.147 \\
Asymp. Sig. (2-tailed) & .465 \\
\hline
\end{tabular}

a. Test distribution is Normal.

b. Calculated from data.

Sumber : Hasil Olah SPSS 20

Dari Tabel 4.1 Taraf nyata $\alpha$. Asymp.Sig (2-tailed) $0.98>0.05$. Dengan demikian menunjukkan bahwa data residual berdistribusi normal dan model regresi telah memenuhi asumsi normalitas.

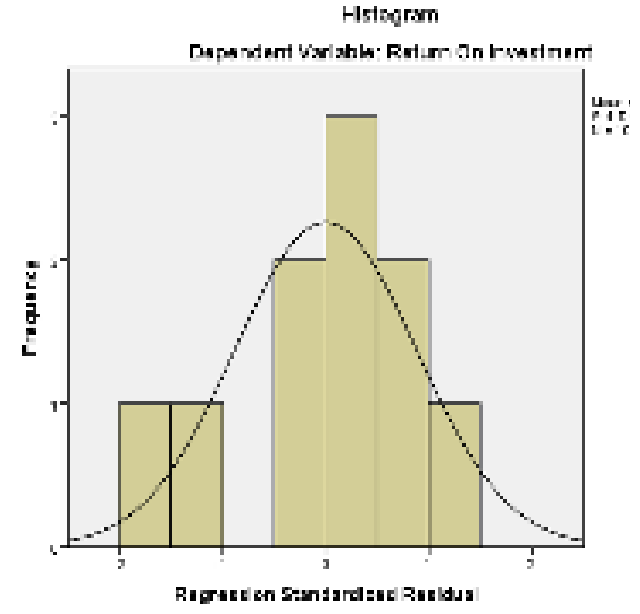

Gambar 4.1 Histogram

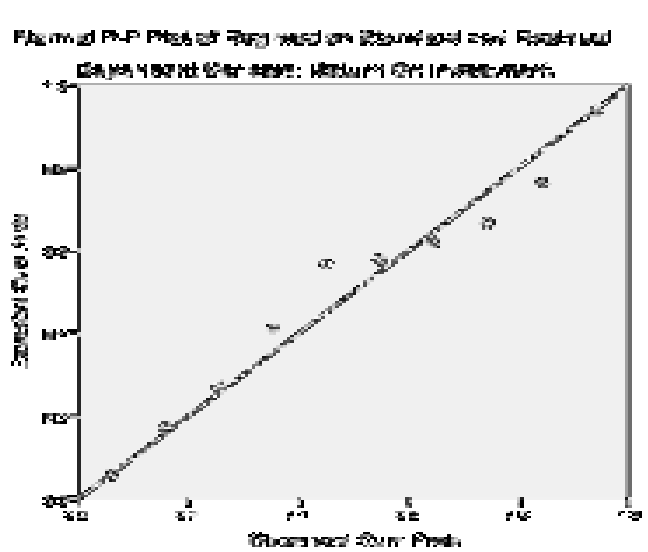

Gambar 4.2 P-Plot

Data residual mempunyai distribusi normal dan model regresi memenuhi asumsi normalitas. Uji normalitas dapat juga dilakukan melalui grafik normal probability plot of 
regression standardized residual. Dan data residual mempunyai distribusi normal dan model regresi memnuhi asumsi normalitas.

Tabel 4.2

Uji Multikolinieritas

\begin{tabular}{|c|c|c|c|c|c|c|c|}
\hline \multirow[t]{2}{*}{ Model } & \multicolumn{2}{|c|}{$\begin{array}{l}\text { Unstandardized } \\
\text { Coefficients }\end{array}$} & $\begin{array}{c}\text { Standardized } \\
\text { Coefficients } \\
\end{array}$ & \multirow[t]{2}{*}{$\mathrm{t}$} & \multirow[t]{2}{*}{ Sig. } & \multicolumn{2}{|c|}{$\begin{array}{c}\text { Collinearity } \\
\text { Statistics }\end{array}$} \\
\hline & $\mathrm{B}$ & Std. Error & Beta & & & Tolerance & VIF \\
\hline 1. (Constant) & -.008 & .076 & & -0.100 & .923 & & \\
\hline Perputaran Kas & -.018 & .004 & -.468 & -4.253 & .004 & .321 & 3.116 \\
\hline Perputaran Piutang & .033 & .007 & .564 & 5.129 & .001 & .321 & 3.116 \\
\hline
\end{tabular}

a. Dependent Variable: Return On Investment

Tabel 4.3

Uji Autokorelasi

Model Summary

\begin{tabular}{|l|r|r|r|r|r|}
\hline Model & \multicolumn{1}{|c|}{$\mathrm{R}$} & $\mathrm{R}$ Square & $\begin{array}{c}\text { Adjuste } \\
\mathrm{d} \mathrm{R} \\
\text { Square }\end{array}$ & $\begin{array}{c}\text { Std. Error } \\
\text { of the } \\
\text { Estimate }\end{array}$ & $\begin{array}{c}\text { Durbin- } \\
\text { Watson }\end{array}$ \\
\hline 1 & $.986^{\mathrm{a}}$ & .973 & .965 & .01264 & 2.520 \\
\hline
\end{tabular}

a. Predictors: (Constant), Perputaran Piutang, Perputaran Kas

b. Dependent Variable: Return On Investment

Dari Tabel 4.2 dan 4.3, dapat disimpulkan bahwa semua variabel independennya tidak terjadi permasalahan multikolonieritas, heteroskedastisitas, dan autokorelasi, sehingga model regresi dapat digunakan.

Tabel 4.4

\section{Analisis Regresi Linier Berganda}

\begin{tabular}{|c|c|c|c|c|c|c|c|}
\hline \multirow[t]{2}{*}{ Model } & \multicolumn{2}{|c|}{$\begin{array}{l}\text { Unstandardized } \\
\text { Coefficients }\end{array}$} & $\begin{array}{c}\text { Standardized } \\
\text { Coefficients }\end{array}$ & \multirow[t]{2}{*}{$\mathrm{t}$} & \multirow[t]{2}{*}{ Sig. } & \multicolumn{2}{|c|}{$\begin{array}{c}\text { Collinearity } \\
\text { Statistics }\end{array}$} \\
\hline & $\mathrm{B}$ & Std. Error & Beta & & & Tolerance & VIF \\
\hline 1. (Constant) & -.008 & .076 & & -0.100 & .923 & & \\
\hline Perputaran Kas & -.018 & .004 & -.468 & -4.253 & .004 & .321 & 3.116 \\
\hline Perputaran Piutang & .033 & .007 & .564 & 5.129 & .001 & .321 & 3.116 \\
\hline
\end{tabular}

a. Dependent Variable: Return On Investment

Sumber : Output SPSS

Berdasarkan tabel 4.4 dapat diketahui persamaan regresi linear berganda yaitu:

$$
\mathrm{ROI}=-0.008-0.018 \text { Perputaran Kas }+0.033 \text { Perputaran Piutang. }
$$

Artinya : Perputaran Kas memiliki arah hubungan yang negatif terhadap ROI, sedangkan Perputaran Piutang memiliki arah hubungan positif terhadap Return On Investment.

Tabel 4.5

Uji Koefisien Korelasi dan Determinasi

Model Summary ${ }^{b}$

\begin{tabular}{|l|r|r|r|r|}
\hline Model & \multicolumn{1}{|c|}{$\mathrm{R}$} & R Square & $\begin{array}{l}\text { Adjusted } \\
\text { R Square }\end{array}$ & $\begin{array}{l}\text { Std. Error of } \\
\text { the Estimate }\end{array}$ \\
\hline 1 & $.986^{\mathrm{a}}$ & .973 & .965 & .01264 \\
\hline
\end{tabular}


a. Predictors: (Constant), Perputaran Piutang, Perputaran Kas

b. Dependent Variable: Return On Investment

Sumber : Output SPSS

Dari tabel 4.5, dengan penilaian pada uji koefisien korelasi $0,80-1,00$ terdapat nilai $\mathrm{R}$ adalah 0,986 . Hal ini menunjukkan bahwa terdapat hubungan sangat kuat antara perputaran kas $\left(\mathrm{X}_{1}\right)$ dan perputaran piutang $\left(\mathrm{X}_{2}\right)$ terhadap return on investment $(\mathrm{Y})$. Sedangkan untuk uji determinasi terdapat nilai $\mathrm{R}^{2}$ sebesar 0.973. Hal ini menunjukkan bahwa sumbangan (kontribusi) dari variabel independen (perputaran kas dan perputaran piutang) terhadap variabel dependen (return on investment) yaitu sebesar 97.3\%.

Tabel 4.6

Uji T

Coefficients $^{\mathrm{a}}$

\begin{tabular}{|l|r|r|r|r|r|r|r|}
\hline Model & \multicolumn{2}{|c|}{$\begin{array}{c}\text { Unstandardized } \\
\text { Coefficients }\end{array}$} & $\begin{array}{c}\text { Standardized } \\
\text { Coefficients }\end{array}$ & $\mathrm{t}$ & \multirow{2}{*}{ Sig. } & \multicolumn{2}{|c|}{$\begin{array}{c}\text { Collinearity } \\
\text { Statistics }\end{array}$} \\
\cline { 2 - 4 } & \multicolumn{1}{c|}{$\mathrm{B}$} & Std. Error & \multicolumn{1}{c|}{ Beta } & & & Tolerance & VIF \\
\hline 1. (Constant) & -.008 & .076 & & -0.100 & .923 & & \\
Perputaran Kas & -.018 & .004 & -.468 & -4.253 & .004 & .321 & 3.116 \\
Perputaran Piutang & .033 & .007 & .564 & 5.129 & .001 & .321 & 3.116 \\
\hline
\end{tabular}

a. Dependent Variable: Return On Investment

Sumber : Output SPSS

Berdasarkan hasil uji t yang dilakukan pada tabel 4.5 diperoleh hasil sebagai berikut :

1) Uji Variabel Perputaran Kas $\left(X_{1}\right)$

Nilai thitung nya (-) $4.253>$ t tabel 2,364, sedangkan nilai signifikan $0,004<0,05$. Maka Hol di tolak dan Hal di terima, sehingga dari hasil tersebut dapat disimpulkan bahwa secara parsial terdapat pengaruh negatif signifikan antara perputaran kas terhadap ROI.

2) Uji Variabel Perputaran Piutang $\left(\mathrm{X}_{2}\right)$

Nilai t hitung 5.129 $>\mathrm{t}$ tabel 2,364, sedangkan nilai signifikan $0,001<0,05$. Maka Ho2 di tolak dan Ha2 di terima, sehingga dari hasil tersebut dapat disimpulkan bahwa secara parsial terdapat pengaruh positif signifikan antara perputaran piutang terhadap ROI.

Tabel 4.7

Uji F

ANOVA ${ }^{\mathrm{a}}$

\begin{tabular}{|l|r|r|r|r|c|}
\hline Model & \multicolumn{1}{|c|}{$\begin{array}{c}\text { Sum of } \\
\text { Squares }\end{array}$} & df & Mean Square & F & Sig. \\
\hline Regression & .040 & 2 & .020 & 125.18 & $.000^{\mathrm{b}}$ \\
Residual & .001 & 7 & .000 & & \\
Total & .041 & 9 & & & \\
\hline
\end{tabular}

a. Dependent Variable: Return On Investment

b. Predictors: (Constant), Perputaran Piutang, Perputaran Kas

Sumber : Output SPSS

Berdasarkan tabel 4.7 dapat diketahui, hasil $\mathrm{F}$ hitung $125.185>\mathrm{F}$ tabel 4,74, dan hasil nilai signifikan $0,000<0,05$. Maka Ho3 di tolak dan Ha3 di terima, artinya terdapat pengaruh 
signifikan antara perputaran kas dan perputaran piutang secara bersama-sama terhadap tingkat return on investmentpada PT Semen Indonesia (Persero) Tbk. Periode tahun 2008 - 2017.

\section{KESIMPULAN}

Berdasarkan penelitian yang telah dilakukan dan analisis yang telah dijelaskan pada penelitian ini yang berjudul "Pengaruh Perputaran Kas dan Perputaran Piutang Terhadap Return On Investment (ROI) pada PT Semen Indonesia (Persero) Tbk.Periode Tahun 2008 2017", maka dapat diambil kesimpulan sebagai berikut :

1. Perputaran kas secara parsial berpengaruh negatif signifikan antara perputaran kas terhadap ROI pada PT Semen Indonesia (Persero) Tbk. Periode Tahun 2008 - 2017.

2. Perputaran piutang secara parsial ada pengaruh positif signifikan antara perputaran piutang terhadap ROI pada PT Semen Indonesia (Persero) Tbk. Periode Tahun 2008 2017.

3. Terdapat pengaruh signifikan Perputaran kas dan perputaran piutang secara bersamasama terhadap ROI pada PT Semen Indonesia (Persero) Tbk. Periode Tahun 2008 2017.Dengan hubungan yang sangat kuat, serta memberikan kontribusi dengan arah hubungan negatif perputaran kas terhadap ROI dan dan positif antara perputaran piutang terhadap ROI dengan persamaan Regresi Linier Berganda ROI $=-0.008-0.018 \mathrm{Pk}+$ 0.033Pp. Selain itu, dapat dilihat dari nilai Adjusted R Square sebesar 0,973 atau 97.3\% dari variabel ROI dapat dijelaskan atau dipengaruhi oleh perputaran kas dan perputaran piutang.

\section{DAFTAR PUSTAKA}

Arianti, Ririn, dan N. Rusnaeni. (2018). Pengaruh Perputaran Piutang, Perputaran Kas dan Perputaran Persediaan terhadap Profitabilitas PT. Ultrajaya Milk Industry \& Trading Company, tbk., seminar nasional, universitas pamulang, Ekonomi, Program Studi D3 Akuntansi, 13 desember 2018 issn: 9772599343004.

Danang, Suyanto. (2013).Dasar-dasar Manajemen Keuangan Perusahaan, Yogyakarta: Penerbit CAPS.

Danim, Sudarwan dan Yunan Danim, “Administrasi Sekolah dan Manajemen Kelas”, Penerbit Pustaka Setia, Bandung 2010.

Fahmi, Irham. (2014).Pengantar Manajemen Keuangan, Bandung: Penerbit Alfabeta, Cetakan Ke-3.

Kasmir. (2010). Pengantar Manajemen Keuangan, Jakarta: Penerbit Kencana Prenada Media Group.

Munawir. (2012). Analisis Informasi Keuangan, Yogyakarta: Penerbit Udayana Liberty.

Riyanto, Bambang. (2011). Dasar-dasar Pembelanjaan Perusahaan,Yogyakarta: Edisi 1 Cetakan ke-11, Penerbit Udayana BPFE.

Sugiyono. (2012). Metode Penelitian Kuantitatif, Kualitatif dam R\&D, Bandung: Penerbit Alfabeta.

Sugiyono. (2015). Metode Penelitian Pendidikan, Bandung: Penerbit Alfabeta. 